\title{
Erratum to: Recent developments in immobilizing titanium dioxide on supports for degradation of organic pollutants in wastewater-A review
}

\author{
M. H. Alhaji ${ }^{1,2}$ - K. Sanaullah ${ }^{2}$ A. Khan ${ }^{2}$ - A. Hamza ${ }^{3}$ A. Muhammad ${ }^{3}$. \\ S. I. Mustapha ${ }^{4}$ A. R. H. Rigit ${ }^{5}$ S. A. Bhawani ${ }^{6}$
}

Published online: 13 June 2017

(C) Islamic Azad University (IAU) 2017

Erratum to: Int. J. Environ. Sci. Technol.

DOI 10.1007/s13762-017-1349-4

The name of the author S.I. Mustapha contains errors in the original article.

The online version of the original article can be found under doi:10. 1007/s13762-017-1349-4.

M. H. Alhaji

hajialhaji2000@gmail.com

1 Nigeria Institute of Leather and Science Technology, Zaria, Nigeria

2 Department of Chemical Engineering and Energy Sustainability, Universiti Malaysia Sarawak (UNIMAS), Kota Samarahan, Malaysia

3 Department of Chemical Engineering, Ahmadu Bello University, Zaria, Nigeria

4 Department of Chemical Engineering, University of Ilorin, Kwara, Nigeria

5 Department of Mechanical and Manufacturing Engineering, Universiti Malaysia Sarawak (UNIMAS), Kota Samarahan, Malaysia

6 Department of Chemistry, Faculty of Resource Science and Technology, Universiti Malaysia Sarawak (UNIMAS), Kota Samarahan, Malaysia 